\title{
Tekoälyn yhteiskehittäminen julkisella sektorilla
}

\author{
Jari Autioniemi
}

\section{ABSTRACT \\ Artificial intelligence co-creation \\ in the public sector}

This article assesses the steps of AI co-creation in the public innovation ecosystem. However, in order to understand $\mathrm{AI}$ in the right context, two aims need to be fulfilled first. The limits and possibilities of $\mathrm{AI}$ in public administration are assessed by examining the contributions of AI research, phenomenology and philosopher Hubert Dreyfus. According to the article, the simpler the rules, the better for AI. Therefore, hierarchical and bureaucratic structures are best for AI application. However, bureaucratic structures are poor in innovating and exploration - AI innovations included. After this, co-creation is introduced as a way of innovating $\mathrm{AI}$ in the public sector. For identifying new opportunities for co-production, different forms of cross-sectoral and citizen involvement are needed.

Key words: artificial intelligence, public administration, public innovation, co-creation

\section{JOHDANTO}

Tämän artikkelin tarkoituksena on arvioida mahdollisuuksia tekoälyn innovoinnille julkisella sektorilla. Tekoäly nähdään tällä hetkellä yhtenä innovaation lähteenä, ja sen vaikutukset tulevaisuuden työelämään tulevat olemaan valtavia. Suomessa aiheeseen liittyy kiistämätöntä poliittista momentumia: Valtioneuvoston kanslia $(2019,2018,2017)$ on julkaissut tekoälystä ja digitalisaatiosta esimerkiksi algoritmisesta päätöksenteosta, ohjelmistorobotiikasta ja työmarkkinoista digimurroksessa. Tekoäly julkishallinnossa on iso aihe, jonka tutkimus on aluillaan. Tutkimuksesta tekee vaikean se, että tutkijoilla tulisi olla samaan aikaan ymmärrystä ei pelkästään tekoälytutkimuksesta, vaan julkisjohtamisesta sekä julkisesta innovaatiosta, kuten artikkeli osoittaa.

Artikkelin teoreettinen viitekehys perustuu julkiseen innovaatiotutkimukseen ja innovaatioekosysteemin käsitteeseen. Mutta miksi artikkelissa ylipäätään käytetään innovaation käsitettä? Innovaatio on melko uusi käsite julkisella sektorilla - toisinaan sitä käytetään jopa halventavassa merkityksessä. Keskeisin syy tähän löytyy tekoälyn ja julkishallinnon luonteesta. Esimerkiksi OECD:n (2019) mukaan julkishallintojen olisi hyvä kehittää ekosysteemejä luotettavan tekoälyn luomiseen. Innovaatioekosysteemin mekanismien tulisi perustua tekoälyyn liittyvän tietämyksen jakamiseksi eri sidosryhmien välillä, jota voidaan kutsua yhteiskehittämiseksi. Artikkelin tavoitteena onkin arvioida niitä mekanismeja, joihin tämä tietämyksen jakaminen voisi tekoälyn julkisessa innovoinnissa perustua. Yleensä innovaatioekosysteemi perustuu yhden teknologian kehittämiseen eri toimijoiden toimesta (Jackson 2011). Innovaatioekosysteemiä kuvaillaan esimerkiksi kehittämisen systeemisyyden, digitaalisuuden, avoimuuden, eri organisaatioiden kyvykkyyksien ja markkinavoimien kautta (Oh ym. 2016).

Kirjallisuudessa tiedostetaan, että julkinen sektori vaatii radikaalisti uusia innovaation muotoja (Bommert 2010; Harris \& Albury 2009; Eggers \& Singh 2009; Nambisan 2008). Harrisin ja Alburyn (2009) mukaan nykyinen julkinen sektori ei kykene luomaan innovaatioita, jotka ovat välttämättömiä yhteiskunnallisten muutosten ratkaisemisessa. Marchin (1991) argumenttia soveltaen, julkisissa organisaatiossa tutkimisen (exploration) ja hyödyntämisen (exploitation) suhde on epätasapainossa: hyödyntämiseen on kiinnitettävä erityistä huomiota, sillä julkinen organisaatio korostaa hyödyntämistä edellisen kustannuksella. 
Artikkelin tavoitteina on tarkemmin vastata seuraaviin kysymyksiin:

1. Julkisen innovaation ongelma: Millä vaiheilla tekoälyä voitaisiin yhteiskehittää julkisella sektorilla? Ennen kuin kysymystä voidaan arvioida, on ensin vastattava kahteen alakysymykseen:

2. Tekoälytutkimuksen ongelma: Mitkä ylipäätään ovat tekoälyn rajat ja mahdollisuudet?

3. Hallintotieteellinen ongelma: Mitkä julkishallinnon rakenteet ja periaatteet soveltuvat tekoälylle?

Artikkelin pyrkimyksenä on täyttää tutkimusaukkoa, joka liittyy tekoälytutkimuksen kehittämiseen julkishallinnossa. Artikkeli on laadullinen kirjallisuustutkimus, jonka pyrkimyksenä on tuottaa narratiivinen kokonaisuus tutkittavasta ilmiöstä. Kirjallisuustutkimuksella voidaan arvioida teoriaa, rakentaa kokonaiskuvaa asiakokonaisuudesta, tunnistamaan ongelmia ja kuvata teorian kehittymistä historiallisesti. (Efron \& Ravid 2019: 21.) Artikkelin kohdeyleisönä voidaan pitää esimerkiksi julkishallinnon kehittäjiä, julkisjohtajia sekä ylipäätään e-hallinnosta kiinnostuneita tutkijoita. Kohdeyleisö johtuu artikkelin aihepiiristä, jossa yhdistyy julkishallinnon reformointi, julkisen johtamisen tulevaisuus ja digitalisaatio.

Julkiseen innovaatioon ei tule siirtää mekaanisesti käsitteitä tai uskomuksia perinteisestä innovaatiotutkimuksesta. Ensinnäkin on huomioitava eri innovaatioiden moninaisuus. Innovaatiot eivät synny samalla tavalla 2000-luvulla kuin 1900-luvulla. Yritysten innovaatiojohtaminen on edelleen innovaatiotutkimuksen keskiössä: julkisia johtamisinnovaatioita ei ole juurikaan käsitelty uutta julkisjohtamisen ja informaatioteknologian hyödyntämistä lukuun ottamatta. (Lovio \& Kivisaari 2010, 13-16.) Artikkelissa innovaatio voidaan määritellä uusien elementtien tuomiseksi julkisiin palveluihin, olkoon kyseessä sitten uuden tiedon soveltaminen, muutokset organisaatiotavoissa tai johtamisen kehittämisessä (de Vries ym. 2014). Julkishallinnon kehittäjille lienee tuttua toteamus, jonka mukaan julkishallinto on jatkuvassa muutostarpeessa. Käsitteet kuten modernisointi, reformointi ja uudistaminen ovat hallintotieteellisessä mielessä lähellä toisiaan (Pollitt
\& Bouckaert 2011, 2; Bouckaert 2010, 51-52; Savoie 2010, 273). Nyt innovaation käsite on vallannut alaa julkishallinnossa, kenties markkinaehtoisten reformien seurauksesta.

Hallintotieteissä on tarpeellista miettiä innovaatioita sosiaalisen ja yhteiskunnallisen kontekstin kautta. Sosiaalisilla innovaatioilla tarkoitetaan innovatiivisia toimintoja ja palveluita, joiden päämääränä on sosiaalisen tarpeen tyydyttäminen. Innovaation perinteiset talousmallit ovat rajallisia sosiaalisten innovaatioiden jäsentämisessä, sillä talousinnovaatiota ajavat organisaatiot tavoittelevat lähinnä taloudellista voittoa. Entistä suurempi osa taloudesta perustuu asioihin, kuten terveyteen ja koulutukseen, jotka ovat julkisen politiikan perinteistä aluetta. (Mulgan 2006.) Sosiaalisia innovaatioita voidaan ajatella Veblenin (2009) tuotanto- ja rahamotiivin erottelun kautta. Kun tuotantomotiivilla tarkoitetaan jonkin hyödyllisen tuottamista yhteiskunnalle, rahamotiiville on viime kädessä yhdentekevää, millaista yhteiskunnallista arvoa taloudellisesti kannattava toiminta tuottaa.

Julkishallinnon uudistamisen keskiössä vaikuttavat e-hallinto, sähköiset palvelut ja digitalisaatio. Digitalisaatio on sidoksissa julkishallinnon rakenteisiin, toimien ja palveluiden kehittämiseen ja johtamiseen. Julkisten palveluiden kehittäminen merkitsee palveluiden parempaa koordinointia ja organisointia: yksi kehittämisen työkaluista on informaatioteknologian mahdollisuudet palveluiden laadun kehittämiseen, kustannusten alentamiseen ja itsepalvelun lisäämiseen. (Vainio ym. 2017, 5, 27.) Usein ajatellaan, että teknologia edustaa organisaatioissa käytettäviä välineitä, jotka parantavat toiminnan tehokkuutta: tämän vastakohtana teknologiaa voidaan kohdella epävakaana ja vaikeasti ennustettavana ilmiönä (Plesner ym. 2017, 1177). Esimerkiksi tekoäly voi johtaa siihen, että standardisointi ja autonomian väheneminen koskettavat tulevaisuudessa myös korkean osaamisen työtä (Petrakaki \& Kornelakis 2016). E-hallinto voi johtaa kasvokkain tapahtuvan asiakaspalvelun vähenemiseen, mikä vaikeuttaa asiakkaiden tilanteellisten tekijöiden hahmottamista viranomaisen toimesta (Jansson \& Erlingsson 2014). Digitalisaatiota tulisi tutkia julkishallinnon kontekstuaaliset tekijät huomioiden: digitalisaatio julkisella sektorilla poikkeaa yksityisen sektorin käytännöistä esimerkiksi lakiin ja politiikkaan 
nojaavasta luonteestaan sekä organisaatiorakenteistaan johtuen (Plesner ym. 2017). Tätä artikkelia on pyritty kirjoittamaan kyseinen ohjenuora huomioiden.

Tekoälyn rajoista ja mahdollisuuksista on olemassa paljon tutkimuskirjallisuutta (ks. esim. Collins 2000; Polit \& Godo 2006; Angulo \& Talbert 2007; Bengio ym. 2007). Tekoälytutkimuksessa pohditaan esimerkiksi filosofisia kysymyksiä, kuten: voiko tekoäly ajatella, voiko sillä olla mentaalisia prosesseja, tai voiko sen kautta selittää tietoisuutta (Dennett 1995, Searle 1980)? Arkikielessä tekoälyllä tarkoitetaan monia asioita. Artikkeli ottaa lähtökohdakseen tekoälyn sääntöpohjaisena mallina. Tällöin keskiössä on algoritmi, joka määritelmällisesti tarkoittaa yksityiskohtaista ohjetta prosessin suorittamiseksi. Algoritmien yhteiskunnallisten seurausten tutkiminen ei ole pelkkä älyllinen kuriositeetti: algoritmit ovat mukana vaikuttamassa kansalaisten jokapäiväisiin sosiaalisiin suhteisiin, joihin liittyy esimerkiksi kysymys vallasta (Neyland \& Möllers 2016).

Laadullisesti narratiivista kirjallisuustutkimusta voidaan pitää metodisesti kevyimpänä kirjallisuuskatsauksen muotona. Sen tavoitteena on järjestää epäyhtenäinen tieto jatkuvaksi tapahtumaksi. Vaikka kirjallisuustutkimuksessa hankittua tutkimusaineistoa ei ole käynyt läpi systemaattista seulaa, otteella voidaan päätyä johtopäätöksiin ja synteesin tekemiseen. (Salminen 2011, 6-7.) Narratiiviseen kirjallisuustutkimukseen liittyy toisinaan kommentoiva katsaus. Näin on kyseisen artikkelin laita. Tekoälytutkimus hallintotieteissä on vielä alkutekijöissään, ja artikkelissa muodostettu synteesi nojaa osin subjektiivisiin ja normatiivisiin näkemyksiin artikkelin kirjoittajan toimesta. Tämä positio on samalla artikkelin suurin rajoitus.

Artikkelin ensimmäinen kontribuutio on tekoälyn tarkasteleminen hallintotieteissä Dreyfusin tekoälytutkimuksen ja fenomenologian puitteissa. Hallintotieteessä tutkitaan vain harvoin tekoälyn syvempää mielenfilosofista taustaa ja seurauksia julkishallinnon rakenteille tai hallintoteorioille. Artikkelin toinen kontribuutio on tekoälyn yhteiskehittäminen ja sen mahdollisuuksien tarkastelu. Artikkelin kolmas kontribuutio perustuu tekoälyn innovaatioekosysteemin luonnostelemiseen julkishallinnossa.

\section{TEKOÄLY JA KONTEKSTIN ONGELMA}

Filosofi Hubert Dreyfus väittää fenomenologiaan (ks. esim. Husserl 2012, Heidegger 2002 ja Merleau-Ponty 2012) nojaten, että inhimillinen toiminta nojaa laajaan implisiittiseen ja tulkinnalliseen kontekstiin, jonka tekoälyllinen mallintaminen on hyvin haastavaa tai mahdotonta. Dreyfusin työ vilisee mainintoja kontekstista (context), taustasta (background) ja tilanteesta (situation). Konteksti on jotain, jota voidaan kutsua kaiken toimintamme taustalle olevaksi implisiittiseksi ymmärrykseksi maailmasta: se on väistämätön mielenominaisuutemme. Mikään inhimillinen toiminta ei tapahdu kontekstin ulkopuolella, olkoon kyseessä sitten sanan ymmärtäminen, lauseen kääntäminen tai säännön seuraaminen. Tässä mielessä Dreyfusin kontekstin käsite on lähellä taustan käsitettä. Jokainen asia merkitsee jotakin suhteessa määrättyyn taustaan. Esine edessäni on vasara, koska sillä voidaan hakata nauloja, tämä taas näppäimistö, kun kirjoitan artikkelia jne. Taustalla ei kuitenkaan tarkoiteta vain toiminnan pragmaattista kontekstia. Tausta on kontekstia syvällisempi ilmiö. Taustaan liittyy ajatus kulttuurisesta elämänmuodosta, joka toimii kaikkien käytäntöjen lopullisena perustana. (Dreyfus 1979, 1992; Andler 2000, 140-141, 144-145.)

Dreyfusin kontekstin käsite ei ole tuomio tekoälytutkimusta kohtaan. Jo perinteisessä tekoälytutkimuksessa ymmärrettiin, etteivät ärsykkeet tai representaatiot ilmene merkityksistä riippumattomina. Kontekstiongelma voitaisiin ratkaista niin, että kulloisenkin kontekstin asiaankuuluvat piirteet hahmotettaisiin ja representoitaisiin toimivasti. Näin ollen määrättyihin premisseihin perustuva päättely reagoisi kulloiseenkin ärsykkeeseen oikealla tavalla, kun se samalla ottaisi huomioon kontekstin olennaisimmat representaatiot. Tällaista näkökantaa voidaan kutsua maltilliseksi kontekstualismiksi. Kontekstiongelman ratkaiseminen on hyvin vaikeaa. Maltillisen kontekstualismin vastakohtana voidaan pitää kontekstieliminativismia, jonka mukaan kysymys kontekstiongelmasta on näennäinen. Oikeiden elementaaristen prosessien löytäminen poistaa näkemyksen mukaan myös kysymyksen kontekstista. (Andler 2000, 141-142.) 
Dreyfusin työ osoittaa kontekstieliminativismin lisäksi myös maltillisen kontekstualismin ongelmalliseksi. Tämän ymmärtäminen edellyttää Dreyfusin argumentin tarkempaa läpikäyntiä. Kolmas Dreyfusin keskeinen käsite on situaatio, joka perustuu muttei pelkisty ympäristön objektiivisiin ominaisuuksiin. Situaation ongelmallisuus tekoälyn suhteen on siinä, ettei tilannetta voida kääntää representaatioiksi, jotka auttaisivat systeemiä muodostamaan kulloinkin oikean toimintamallin. Situaatio on aina holistinen: sen elementtejä ei ole olemassa kontekstin ulkopuolella, tai ne eivät ainakaan kanna sisäistä merkitystä. Pelkästään situaatio voi tarjota niille merkityksen ja relevanssin. Näin ollen järjestelmä ei voi arvioida tilannetta tämän elementtien perusteella. Toisaalta situaatio sisältää järjestelmän odotukset ja päämäärät, minkä johdosta ympäristön holistista mahdollisuuksien avaruutta ei ole mahdollista arvioida ennalta. Kuten on kontekstin laita, situaatio ei tarkoita maltillisen kontekstualismin tuomiota: kysymys on siitä, miten kyseinen viitekehys ratkaisisi situaation luonteen. Koska konteksti sisältää taustan kokonaisuudessaan, sen mallintaminen maltillisen kontekstualismin toimesta on haastavaa. (Andler 2000, 143.)

Inhimillinen ja arkipäiväinen toiminta voi vaikuttaa hyvin yksinkertaiselta: se voi tarkoittaa, että kysymys: "Voisitko antaa minulle suolaa?" ymmärretään oikein ja siihen vastataan oikealla tavalla. Tekoälytutkimuksen Graalin malja on, voidaanko inhimillisestä toiminnasta muodostaa eksplisiittinen, ongelmaton ja yksinkertainen toimintojen lista, jota tekoäly soveltaisi ongelmattomasti. Dreyfusin mukaan kontekstin ja taustan hallinta sekä kääntäminen äärelliseen ohjelmointikieleen on likipitäen mahdotonta. Tämä alati muuttuva konteksti tulisi joka tapauksessa huomioida, kun esimerkiksi algoritmien yhteiskunnallista valtaa tutkitaan (Neyland \& Möllers 2016). Ehkä suurin ongelma on siinä, että konteksti ja tausta toimivat eksistentiaalisilla eivätkä loogisilla oletuksilla. Merkitysten taustalla on meille jotain merkitystä inhimillisinä olentoina, jota tekoäly ei tule koskaan ymmärtämään. (Andler 2000, 143-145.) Ludwig Wittgensteinin (1981) kautta ilmaistuna, tekoälytutkimuksen kohteena on kieli ja kieltä taustoittava elämänmuoto.

Dreyfusin osoittama perusongelma on jäänyt ratkaisematta (Bengio ym. 2007). Tällä hetkellä tekoäly kykenee ymmärtämään, valvomaan, järkeilemään, ennustamaan, vuorovaikuttamaan, oppimaan ja parantamaan suoritustaan (Mehr 2017). Joissain näissä tekoäly on huomattavasti ihmistä tehokkaampi. Inhimillisen kokemuspiirin kirjoa ajatellen tekoälyn sovellusalueet ovat edelleen pieniä. Sovellusalueita ei kuitenkaan pidä vähätellä. Kysymys on jälleen kerran kontekstista: mitä pienempi toimintakonteksti tekoälylle tarjotaan, sen parempi. Suuret kokonaisuudet tulevat kyseeseen, kun niitä voidaan representoida loogisessa muodossa. Tekoälyn sovellusalueen sääntöjen ja toimintamallien tulee olla tarkoin määriteltyjä. Mutta mitä nämä sovellusalueet voisivat tarkemmin olla julkishallinnossa?

\section{JULKISHALLINNON KOLME OPPIA}

Kysymys tekoälyn soveltamisesta julkishallintoon on kysymys siitä, millaiseksi tieteenalaksi hallintotiede ymmärretään. Hallintotieteiden perinteinen kiista on, tulisiko johtaminen ymmärtää tieteenä tai taitona, faktoista tai arvoista lähestyvänä intressin kohteena. Johtamisen rajoitettu rationaalisuusteoria nojaa siihen, että arvoulottuvuus on ulkopuolinen ilmiö hallinnolliselle päätöksenteolle. Vastakohdan rajoitetulle rationaalisuusteorialle muodostaa näkemys, jonka mukaan hallinnollinen päätöksenteko on alituisesti alttiina eettisille ja poliittisille arvostuksille. (Riccucci 2010, 1-2, 31; Simon 1946; Hyyryläinen 2012.) Viimeisimmät julkisen sektorin ongelmanasettelut vievät heiluria taas arvojen puolelle. Vartolan (2009) mukaan hallintotieteen perimmäinen kysymys on, millaisilla rakenteilla ja johtamis- ja toimintakäytännöillä organisaatiot kykenevät olemaan vaikuttavia, laadukkaita, tehokkaita ja tuloksellisia.

Julkishallintoa voidaan tarkastella alustavasti systeemisestä näkökulmasta. Systeemiajattelussa valtio koostuu osista, jonka jokaisella osalla on suunniteltu ja tarkoituksenmukainen paikka ja tehtävä. Osajärjestelmät, kuten keskushallinto tai kunnat ovat oleellinen osa kokonaisuutta: osajärjestelmät tarvitsevat kokonaisjärjestelmää toimiakseen, eikä kokonaisjärjestelmää olisi olemassa ilman osajärjestelmiä. Julkishallintoa on mahdollista tarkastella toimintaympäristöä tunnustelevana järjestelmänä. Julkishallinto vastaan- 
ottaa erilaisia syötteitä ympäristöltä, käsittelee niitä, tekee päätöksiä ja muodostaa lopputuotoksia. Tuotokset vaikuttavat vuorostaan ympäristöön, minkä vuoksi seuraavat julkishallinnon vastaanottamat syötteet muuttuvat. (Nyholm ym. 2016, 71-75; Easton 1965.)

Max Weberin byrokratiateoriaa pidetään hallintotieteessä perustavana hallintoteoriana. Julkishallinnon ajatteleminen järjestelmänä on klassiselle byrokratiateorialle mitä otollisinta maaperää: tarkoin rajatut hallintofunktiot ja normien mukaiset työtehtävät mahdollistavat tehokkuuden.

- Byrokratiaa sitoo säännöt ja viralliset funktiot

- Organisaatiolla on tarkoin määritelty toimivalta, joka sisältää velvollisuuden työnjaon mukaisiin tehtäviin, auktoriteettiaseman käskyjen antamiseen ja pakkokeinojen järjestelmän ja määräykset niiden käytöstä

- Organisaatiossa on virkahierarkia

- Toimintaa ohjaavat oikeudelliset normit

- Kuten organisaatioilla, virkamiehillä on tarkoin määritelty toimivalta

- Hallinnolliset päätökset ja säädökset taltioidaan kirjallisesti

- Virkamies on systemaattisen kurin ja valvonnan alaisuudessa (Vartola 2009; Weber 1972, 125-128.)

Julkishallintoa on reformoitu viimeisten vuosikymmenten aikana yksityisen sektorin käytännöillä, mikä on tarkoittanut irtiottoa ainakin joistain byrokratian piirteistä. Uudistusten taustalla on ollut tyytymättömyys julkishallinnon tilaa ja toimintaa kuin myös rahoituksellista perustaa kohtaan. Reformien taustalla muodostui uuden julkisjohtamisen (New Public Management, NPM) doktriini, joka toimi julkisen sektorin modernisaation ohjenuorana. Doktriini tarjoaa julkiselle sektorille lääkkeeksi johtamista. (Lähdesmäki 2003, 9-10.) NPM ei kuitenkaan pelkisty managerialistisiin käytäntöihin, vaan koskettaa myös laajempaa ideologista keskustelua julkisen sektorin roolista.

NPM:n hallintoreformit ovat pelkistyneet 1980- ja 1990-lukuun, mutta se vaikuttaa edelleen ideoiden tasolla julkishallinnossa. NPM on tarkoittanut markkinaohjauksen suosimista, henkilöstön toimintavapauden lisäämistä ja val- tuuttamista, virkavaltaisuuden vähentämistä ja asiakaspalveluun panostamista. Julkisjohtajan yrittäjämäisyys korostuu aikana, jolloin julkishallinto läpikäy reformia. NPM on merkinnyt johtamisen muuttumista aktiivisemmaksi ja joustavammaksi, jolloin dynaamisen ympäristön vaatimukset huomioitaisiin. Uudistamisessa asettuvat puheen tasolla vastakkain karikatyyrit "perinteinen byrokraatti" ja "moderni julkisjohtaja". Byrokraatin toiminta muistuttaa muodollisuutta, virheettömyyttä ja ennalta sovittujen menettelytapojen noudattamista. Julkisjohtaja on tuloskeskeinen, dynaaminen ja tulevaisuuteen orientoitunut yksilö, jolla on toimintavapautta resurssien käytössä ja toiminnan suuntaamisessa. Julkisjohtaja asettuu aika ajoin normien ja menettelytapojen yläpuolelle. (Lähdesmäki 2003, 70-71.)

NPM:n seurauksesta julkista toimintaa on johdettu tehokkuuden (efficiency), taloudellisuuden (economy) ja vaikuttavuuden (effecitiveness) arvoilla. Donald Menzel $(2005,25)$ korostaa tehokkuusarvojen ohella neljännen e:n eli etiikan (ethics) merkitystä julkishallinnossa. Hallinnon etiikan pyrkimyksenä on moraalisten ja eettisten periaatteiden soveltaminen julkishallinnossa ja julkisorganisaatioiden päätöksenteossa (ks. Cooper 2001, 1-36). Etiikan kysymyksenasetteluihin onkin alettu kiinnittää enemmän huomiota: on selvää, että etiikka on julkiselle sektorille olennaisesti tärkeämpää kuin muille sektoreille. Julkinen toiminta on sidoksissa yleiseen etuun, eli siihen mihin nähden julkinen sektori perustelee omaa toimintaansa (Autioniemi 2017).

Klassisen byrokratiateorian ja NPM:n lisäksi puhutaan uudesta julkishallinnasta (New Public Governance, NPG) (Osborne 2010). Itse hallinnan käsite on luonteeltaan hyvin monisyinen. Yleensä siihen liitetään ilmiöitä, kuten yhteiskunnan sektoreiden rajojen häilyminen, eri arvolähtökohtien yhteensovittaminen, kansalaisten osallistaminen sekä toimijoiden väliset yhteistyömallit. Tässä tapauksessa valtio ikään kuin vetäytyy aikaisemmasta asemastaan ongelmanratkaisijana ja pyrkii tarjoamaan muille toimijoille mahdollisuuden olla mukana ratkaisemassa yhteiskunnallisia ongelmia. Aihepiiri ei sikäli ole mitenkään uusi: voidaan jopa väittää, että hallinnassa on kyse keisarin uusista vaatteista (Vartola 2009). 
Siinä missä klassinen byrokratiateoria ja NPM korostivat erityisesti organisaation sisäisiä käytäntöjä, NPG:n huomio kiinnittyy organisaatioiden välisiin suhteisiin osana verkostoja. Eri sektorien väliset toimijat ovat harvoin tasaarvoisessa tilanteessa, jolloin verkostoissa vallitsee yleisesti valtataistelun kaltaisia konfliktiperustaisia ilmiöitä. Verkostojen arvoperusta on moninainen johtuen eri toimijoiden välisistä ristiriitaisistakin preferensseistä. NPG näkee valtion pluraalina että pluralistisena. Se on ensinnäkin pluraali, koska moninaiset itsenäiset toimijat vaikuttavat julkiseen sektoriin ja julkisten palveluiden tuottamiseen. Toisaalta se on pluralistinen, sillä lukuisat prosessit vaikuttavat poliittiseen päätöksentekoon. (Osborne 2010, 9-10.)

Taulukko 1. Julkishallinnollisen tutkimuksen kolme hallintomallia ja niiden erityispiirteet (Osborne 2010, 3-7 mukaillen)

\begin{tabular}{|c|c|c|c|}
\hline & Byrokratiateoria & Uusi julkisjohtaminen & Uusi julkishallinta \\
\hline Periaate & $\begin{array}{l}\text { Laillisuusperiaatteen } \\
\text { hallitsevuus }\end{array}$ & $\begin{array}{l}\text { Yksityisen sektorin } \\
\text { johtamiskäytännöt }\end{array}$ & $\begin{array}{l}\text { Hallinta sosio- } \\
\text { poliittisena ongelmana } \\
\text { ja yhteiskunnallisena } \\
\text { ongelmana }\end{array}$ \\
\hline Mekanismi & $\begin{array}{l}\text { Hierarkkisesti eli ylhäältä } \\
\text { alaspäin määräytyvät } \\
\text { säännöt ja ohjeet }\end{array}$ & $\begin{array}{l}\text { Johtaminen käytäntönä } \\
\text { teorian sijaan, vastakohtana } \\
\text { perinteiselle hallinnolliselle } \\
\text { periaatteelle pitää } \\
\text { etäisyyttä konkreettisista } \\
\text { ongelmista }\end{array}$ & $\begin{array}{l}\text { Julkinen politiikka, } \\
\text { eli miten eliitit ja } \\
\text { verkostot aikaansaavat } \\
\text { yhteistyössä päätöksiä eri } \\
\text { arvolähtökohdista käsin }\end{array}$ \\
\hline Oikeutus & $\begin{array}{l}\text { Byrokratian keskeinen } \\
\text { rooli politiikan (policy) } \\
\text { tekemisessä ja } \\
\text { implementoinnissa }\end{array}$ & $\begin{array}{l}\text { Yrittäjämäinen johtajuus } \\
\text { julkisissa organisaatioissa } \\
\text { aikaansaa tehokkuutta }\end{array}$ & $\begin{array}{l}\text { Perinteisen } \\
\text { byrokratiateorian } \\
\text { uudelleenarviointi ja } \\
\text { tehokas soveltaminen } \\
\text { jälkimodernissa valtiossa }\end{array}$ \\
\hline Välineet & $\begin{array}{l}\text { Politiikan ja hallinnon } \\
\text { kahtiajako organisaation } \\
\text { sisällä, inkrementaalinen } \\
\text { budjetointi }\end{array}$ & $\begin{array}{l}\text { Syötteet, tuotokset, } \\
\text { arviointi, tuottavuus } \\
\text { ja auditointi, julkisten } \\
\text { palveluiden hajauttaminen, } \\
\text { kustannussäästäminen }\end{array}$ & $\begin{array}{l}\text { Huomion kiinnittäminen } \\
\text { NPM:n aikaansaamien } \\
\text { sopimusten hallintaan, } \\
\text { verkostojen ja } \\
\text { kumppanuuksien } \\
\text { löytäminen }\end{array}$ \\
\hline $\begin{array}{l}\text { Julkisten } \\
\text { palvelujen } \\
\text { tuottaminen }\end{array}$ & $\begin{array}{l}\text { Asiantuntijoiden ja } \\
\text { "byrokraattien" } \\
\text { hegemonia }\end{array}$ & $\begin{array}{l}\text { Markkinat, } \\
\text { kilpailuttaminen ja } \\
\text { sopimukset }\end{array}$ & $\begin{array}{l}\text { Verkostojen hallinta eri } \\
\text { organisaatioiden välillä }\end{array}$ \\
\hline
\end{tabular}

\section{TEKOÄLY SOVELTUU HALLINTO-OPPEIHIN VAIHTELEVASTI}

Dreyfusin pääargumentti on, että tekoälylle on miltei mahdotonta opettaa kontekstin, taustan ja tilanteen käsitteitä. Näin ollen on oletettavaa, että tekoälyä voidaan soveltaa parhaiten ympäristössä, jossa kontekstuaalisuus pysyy minimissä. Byrokraattisessa hallinnossa päätöksenteon säännöt ovat tekoälylle yleisiä, vakaita ja helposti opittavia. Tässä hallinto-opissa politiikan ja hallinnon dikotomia on vahvasti läsnä, eikä tekoäly ajaudu vaikeasti hahmotettavien eettisten tai ideologisten kysymystenasettelujen piiriin.

Toinen läpikäyty hallinto-oppi on uusi julkisjohtaminen (NPM), joka korostaa yksityisten johtamiskäytäntöjen soveltamista julkisella sektorilla. Läsnä ovat taloudellisuuden, tehokkuu- 
den ja vaikuttavuuden arvot. Johtamisdoktriinissa korostuu johtamistyön käytäntö. Johtuen käytännön johtamisen relativistisuudesta, tekoälyä on vaikea soveltaa kyseisessä ympäristössä. Samalla huomionarvoista on, että NPM korostaa julkisen toiminnan tehokkuuden mittaamisessa taloudellisia kriteereitä, joiden analysoimiseen tekoälyllä löytyy potentiaalia.

Uusin hallinto-oppi on uusi julkishallinta (NPG), jolle keskeistä on verkostojen ja kumppanuuksien löytäminen, eri arvomuotojen hyväksyminen, kansalaisten osallistuminen ja kuuleminen. Näin ollen se sisältää hallintomalleista eniten kontekstuaalisia, taustoittavia ja tilanteellisia tekijöitä. Tämä merkitsee tekoälyn sovellusalueen pienuutta. NPG ei hyväksy yksistään taloudellisia mittareita hyvän hallinnon arvioinnissa: hallinto-opissa pyritään esimerkiksi sovittamaan eri arvolähtökohdista tulevien toimijoiden välisiä intressejä. Siinä missä aikaisemmin on puhuttu hallinnon tehokkuudesta, puhutaan nyt myös eettisyydestä ja yhteiskunnallisesta vaikuttavuudesta. Mitä enemmän hallintoon vaikuttaa arvokeskustelu, sitä lähempänä ollaan Dreyfusin mainitsemaa taustan käsitettä, joka sisältää elämänmuodon ja kulttuuristen käy- täntöjen perustan. Näiden kysymysten äärellä tekoälyllä ei toistaiseksi liene käyttöä. Lisäksi julkishallinnossa edellytetään eettisyyden lisäksi inhimillistä kanssakäymistä, verkostojen luomista ja sosiaalisia taitoja. Verkosto tarkoittaa epämuodollisuuden kasvua ja tekoälyn sovellettavuuden heikentymistä.

Tekoälyn sovellusala julkishallinnossa pelkistyy mahdollisimman formaaleihin rakenteisiin, jotka eivät edellytä Dreyfusin oletusta laajasta tulkinnallisesta kontekstista. Tekoälyn etuja julkisella sektorilla ovat kustannusten laskeminen, toiminnan nopeutuminen ja resurssien allokointi monimutkaisempiin tehtäviin, mikä merkitsee ruuhkien ja paperityön kevenemistä ja ylipäätään resurssien lisääntymistä (Eggers ym. 2017). Tekoälylle soveltuvia hallinnollisia ongelmia voidaan luonnostella alla olevan taulukon mukaisesti (Mehr 2017). Kysymyksessä on tämän hetkisen tekoälyn sovellusalueet. Tulevaisuudessa hallinnolliset ongelmat voivat olla laajempia. Nykyiset hallinnolliset ongelmat perustuvat resurssien allokointiin, suuriin tietokantoihin, asiantuntijoiden puutteeseen, ennustettavaan skenaarioon, proseduuriin ja monipuoliseen dataan:

Taulukko 2. Tekoälylle soveltuvat ongelmanasettelut (Mehr 2017)

\begin{tabular}{|c|c|}
\hline \multicolumn{2}{|r|}{ Tekoälylle soveltuvat hallinnolliset ongelmat } \\
\hline Resurssien allokointi & $\begin{array}{l}\text { - Tehtävän suorittaminen edellyttää hallinnollista tukea } \\
\text { - Vastausajat ovat pitkiä riittämättömän tuen vuoksi }\end{array}$ \\
\hline Suuret tietokannat & $\begin{array}{l}\text { - Tietokannat ovat tehokkuuden kannalta liian suuria työntekijöille } \\
\text { - Sisäisiä ja ulkoisia tietokantoja voidaan yhdistää tulosten ja löydösten } \\
\text { lisäämiseksi }\end{array}$ \\
\hline Asiantuntijoiden puute & $\begin{array}{l}\text { - Yksinkertaisiin kysymyksiin voidaan vastata, mikä vapauttaa } \\
\text { asiantuntijoita muihin tehtäviin } \\
\text { - Erityiskysymyksiä voidaan oppia asiantuntijoiden tueksi tutkimuksessa }\end{array}$ \\
\hline Ennustettava skenaario & $\begin{array}{l}\text { - Tilanne on ennustettavissa pohjautuen historialliseen dataan } \\
\text { - Ennustaminen auttaa kiireellisissä vastauksissa }\end{array}$ \\
\hline Proseduuri & $\begin{array}{l}\text { - Tehtävä on luonteeltaan itseään toistava } \\
\text { - Syötteillä ja tuotoksilla on binaarinen vastaus }\end{array}$ \\
\hline Monipuolinen data & $\begin{array}{l}\text { - Data sisältää visuaalista/avaruudellista ja auditiivista/kielellistä } \\
\text { informaatiota } \\
\text { - Laadullista ja määrällistä dataa tulee arvioida säännöllisesti }\end{array}$ \\
\hline Esimerkit & $\begin{array}{l}\text { - Chatbotit, kansalaisten auttaminen tiedonetsinnässä ja ohjaaminen } \\
\text { viranomaiselle, dokumenttien kääntäminen, kyselyihin vastaaminen, } \\
\text { raporttien tekeminen }\end{array}$ \\
\hline
\end{tabular}


Jos hallintotieteen ja Weberin pyrkimyksenä on löytää rationaalisin ja tehokkain hallinnon muoto, kuluvalla vuosituhannella tällainen hallintomuoto on tekoälyyn perustuva byrokratia: Tekoäly tullaan ottamaan "annettuna" hallinnollisen tehokkuuden välineenä. Tekoäly on tehokkain byrokraatti, sillä se toistamaan nopeasti proseduureja, jotka ovat luonteeltaan itseään toistavia. Byrokratiassa syötteillä ja tuotoksilla on usein binaarinen vastaus. Tekoälyn kyvyt ovat kuin luotuja byrokratian tarkkoihin rajoihin, kuten tarkoin määriteltyyn tehtävään ja toimivaltaan (Vartola 2009; Weber 1972). Byrokraatille ja tekoälylle tarkka sääntöjen ja normien seuraaminen ja niiden perusteella tapahtuva päätösten muodostaminen ovat otollista maaperä. Mitä parasta, byrokraattinen työnjohto on hierarkkista, jolloin tekoäly on valvonnan alaisuudessa. Automaattiseen päätöksentekoon on kuitenkin suhtauduttava varauksellisesti: jos automaattista päätöksentekoa ylipäätään tehdään, se on rajattava päätöksiin, joita voidaan muuttaa jälkikäteen (Valtioneuvoston kanslia 2018, 20).

Vaikka tekoälyn soveltaminen julkisella sektorilla ei ole pysynyt vauhdissa yksityisen sektorin kanssa, potentiaaliset sovellutusalueet julkisella sektorilla heijastavat yksityisen sektorin sovellutuksia. Pitkällä aikavälillä tekoälystä on hyötyä, jos sille annetaan mahdollisuus oppia: pelkkä yksinkertaisten tietokonetehtävien automatisointi ei riitä. Esimerkiksi Meksikon hallitus pilotoi aloitetta, jossa algoritmit oppivat luokittelemaan kansalaisten hakemuksia ja ohjaamaan ne oikeaan toimipaikkaan. Japanin parlamentissa jäsenet vastaavat kansalaisten kysymyksiin käyttämällä hyödyksi tekoälyn luonnosvastauksia. (Mehr 2017, 6, 8.) Esimerkit nojaavat algoritmien sijaan oppivaan tekoälyyn, joka perustuu ohjattuun ja vahvistettuun koneoppimiseen. Julkisorganisaatiot ovat yksityisen sektorin organisaatioita useammin luonteeltaan byrokraattisia, mikä saattaa helpottaa tekoälyn soveltamista kyseisissä organisaatioissa. Näin on etenkin algoritmien laita, sillä byrokraattisen hallinnon säännöt ja normit ovat, ainakin periaatteessa, yksiselitteisiä ja vähän oppimista edellyttäviä periaatteita.

Julkishallintoa on sitä helpompi koneellistaa, mitä selvemmin se voidaan määritellä syötösten ja tuotosten järjestelmänä, jossa on tarkkarajaiset syy-seuraus- suhteet. Julkishallinto systeemisenä järjestelmänä on lähtökohdan ideaali muo- to (Nyholm ym. 2016; Easton 1965). Byrokratiateoria nojaa vahvasti tähän näkemykseen. On mahdollista, että tekoälyyn nojautuva e-hallinto perustuu ainakin joiltain osin byrokraattisten instituutioiden ja rakenteiden paluuseen. Uudemmat hallintoreformit ovat tuoneet julkisjohtamiseen periaatteita, joiden soveltamisessa tekoäly on ainakin toistaiseksi osoittautunut vajavaiseksi välineeksi. Lähestymistapa merkitsisi miltei väistämättä päätöksenteon arvoulottuvuuden rajaamista pois tekoälyn kehittämiseltä. Mitä arvoneutraalimmaksi julkinen johtaminen ymmärretään, sitä parempaa tukea tekoäly voi tarjota julkisjohtajalle. NPG:n kaltaiset hallintoopit ovat viemässä julkisjohtamista eri suuntaan. Julkinen johtaminen ei ole etiikasta tai yhteiskunnallisista tekijöistä ulkopuolinen ala. Samaa voidaan ajatella tekoälystä. NPG laajentaa tekoälystä käytävää yhteiskunnallista keskustelua ja toivon mukaan itse suunnitteluprosessia. Kyseisen hallinto-opin kautta julkishallinnolla on paremmat mahdollisuudet huomioida sosiaalinen oikeudenmukaisuus digitalisaation aikakaudella.

On perusteltua miettiä, mitkä ovat askelmerkit tekoälyn soveltamiseen julkisella sektorilla. Hila Mehr ehdottaa strategiaksi eettisten riskien minimoimisen ja tekoälyn päätöksenteon välttämisen: tekoälyä tulee käyttää analyyseissä ja prosessien parantamisessa, ei päätöksenteon tukena. Sen ei esimerkiksi pidä tehdä kriittisiä päätöksiä kansalaisista. Yksi tekoälyn ilmeinen heikkous on sen alttius ennakkoasenteille, mikä selittyy usein heikosta ohjelmoinnista tai korruptoituneesta datasta. Paras tapa näiden välttämiseen on käyttää monialaisia asiantuntijoiden kaartia osaksi tekoälyn toimintaa. (Mehr 2017, 13-14.) Toisaalta voidaan ajatella, että automatisoituja päätöksentekojärjestelmiä voidaan soveltaa sellaisten päätösten piirissä, jotka eivät juurikaan tuota harmia päätöksen kohteelle (Valtioneuvoston kanslia 2018, 19). Joka tapauksessa tekoälyn alttius ennakkoasenteille heikentää hallinnon toimintaedellytyksiä. Tehokkuuden periaate edellyttää selkeiden normien olemassaoloa, joita voidaan noudattaa ennakoivasti. Ennakkoasenteet päätöksenteossa asettaisivat hallinnollisen toiminnan kyseenalaiseksi.

Toinen strategia on tehdä tekoäly osaksi laajempaa tuloksiin perustuvaa ja kansalaisia huomioivaa julkishallinnollista ohjelmaa. Tekoälyä ei tule käyttää siitä syystä, että se on uutta ja 
kiehtovaa teknologiaa. Virkamiehillä tulee olla kyky ratkaista ongelmia, ja tekoäly on yksi väline muiden joukossa näiden ongelmien ratkaisemisessa. Jos tekoäly on paras väline tietyn ongelman ratkaisemiseen, sitä tulisi käyttää; jos tekoäly taas ei ole paras väline, sen käyttämistä tulisi välttää. Tekoälyn soveltamisessa tulisi huomioida kansalaiskeskeisyys ja kansalaisilta tuleva palaute tekoälyyn liittyen, mikä poistaisi epäluuloja tekoälyä koskien. Tekoäly tulee vaikuttamaan kansalaisten tapaan olla yhteydessä julkishallinnon kanssa. Tekoäly ei ole ratkaisu julkisen sektorin ydinongelmiin, mutta se on voimakas väline tehokkuuden lisäämisessä. (Mehr 2017, 11-12, 15.)

\section{KOLLABORATIIVINEN INNOVAATIO BYROKRATIASSA}

Edellisen varjolla voidaan todeta, että byrokraattiset rakenteet ovat otollisinta maaperää tekoälyn soveltamiseen. Seuraavaksi herää kysymys, millä tavoin julkisella sektorilla voitaisiin luoda uusia tekoälylle soveltuvia käytäntöjä. Byrokraattiset rakenteet ovat heikkoja innovoinnissa ja tutkimisessa (Petrakaki \& Kornelakis 2016). Näin ollen tekoälyn kehittäminen koskettaa maaperää, joka miltei hylkii uuden luomista. Asian suhteen voidaan luonnollisesti tehdä kompromisseja. Esimerkiksi Birkinshawin ja Gibsonin (2004) mukaan tutkimisen ja hyödyntämisen dikotomiaa voidaan lievittää rakenteellisella ja kontekstuaalisella muodolla. Rakenteellisessa muodossa tutkimista ja hyödyntämistä tehdään organisaation eri yksiköissä, kun taas kontekstuaalisessa muodossa virkamiehet jakavat aikansa kumpaankin. Julkisorganisaatioissa rakenteellinen muoto lienee muodoista järkevämpi, jolloin kehittäminen ei haittaa usein professiolähtöistä työntekoa tai kohtaa organisatorista vastarintaa.

Yksi mahdollinen vastaus tekoälyn kehittämiseen on kollaboratiivinen innovaatio. Sen perusidea on, että julkishallinto käyttää innovoinnissaan laajaa ja moninaista organisaatioiden ja yksilöiden pohjaa (Eggers \& Singh 2009: 98). Sen sijaan, että tekoälyä kehitettäisiin byrokraattisten organisaatioiden ja muodollisten rakenteiden sisällä, huomiota tulisi kiinnittää itse innovaatiolähteisiin. Tämän vuoksi kollaboratiivinen innovaatio on yhteydessä verkostoituneen hallinnon kanssa, jossa hyödynnetään ul- koisten verkostojen ja yhteisöjen luovuuteen ja resursseihin (Bommert 2010; Nambisan 2008). Kollaboratiiviseen innovaatioon kutsutaan kaikki organisaation sisä- ja ulkopuolella, sektoreiden välillä ja kansalaisten keskuudessa, innovaatioprosessin varhaisesta vaiheesta alkaen. Tekoälyn kollaboratiiviseen innovointiin löytyy syitä myös julkisorganisaatioiden ulkopuolelta: esimerkiksi OECD (2019) suosittelee, että tekoälyn suunnittelun on noudatettava luotettavuuden, läpinäkyvyyden ja vastuullisuuden arvoja. Näiden toteutuminen on helpompaa tilanteessa, jossa eri sidosryhmät huomioidaan suunnitteluprosessissa. Näin on etenkin julkisen sektorin laita, jolla on yksityistä sektoria laajempi yhteiskunnallinen vastuu.

Näin ollen painavimmat syyt tekoälyn, julkisen sektorin ja yhteiskehittämisen yhdistämiselle ovat seuraavat:

1. Yksityisen sektorin edelläkävijyys tekoälyn kehittämisessä organisaatioissa

2. Kansalaisten osallistaminen ja hallinnon avautuminen normatiivisena ehtona modernin julkishallinnon kehittämiselle digitaalisena aikakautena

3. Julkishallinnon kulttuuriset ja rakenteelliset esteet innovoinnille

4. Tekoälyn sovellutusalueet byrokraattisissa rakenteissa, joissa korostuvat hyödyntäminen tutkimisen sijaan

5. Verkostomaisen ja eri sektoraalisten toimijoiden välisen yhteistyön tuottama lisäarvo

6. Tekoälyyn liittyvien uhkakuvien hälventäminen ja julkishallinnon legitimiteetin parantaminen

7. Julkinen innovaatio aidosti demokraattisena, sosiaalisena ja avoimena prosessina

8. Positiivinen suhtautuminen julkisen sektorin riskinottoon: eri toimijoiden kollaboraatiossa riskinotto myös laajenee

9. Innovaatioekosysteemit tuottavat ympärilleen enemmän lisäarvoa ja positiivisia ulkoisvaikutuksia kuin siihen osallistuvat toimijat onnistuisivat tuottamaan yksinään

Ajatus eri toimijoiden välisestä yhteiskehittämisestä juontaa yksityisen sektorin avoimen innovaation (open innovation) käsitteeseen. Ajatuksena on, että arvokkaat ideat voivat syntyä yrityksen sisällä tai ulkona - ja myös men- 
nä markkinoille tämän sisä- tai ulkopuolelta (Chesborough 2003, 43). Näin ollen suljettujen innovaatioiden aikakausi on päättynyt, sillä avoimen innovaation ajatellaan lisäävän innovaatioiden määrää ja laatua. Von Hippel (2005) puhuukin demokraattisesta innovaatiosta, jolloin tuotteen tai palvelun asiakkaat pääsevät enenevissä määrin innovoimaan itse: ns. johtokäyttäjien (lead-users) innovaatiot tulevat olemaan menestyvämpiä kuin yrityksen sisällä innovoidut palvelut ja tuotteet, minkä johdosta niitä tulee korostaa.

Moore ja Hartley (2008) väittävät julkisten innovaatioiden erottuvan tuote- ja palveluinnovaatioista viidellä tapaa. Kuten edellä mainittiin, julkiset innovaatiot ylittävät organisaation rajat ja kiinnittävät huomiota sinne, missä yhteiskunnallisesti tuottoisaa toimintaa tapahtuu. Toiseksi, julkiset innovaatiot kiinnittävät huomiota uusien resurssilähteiden etsimiseen. Kolmanneksi, julkishallinnolla on kyky koota ja määritellä uudelleen yksityisten tahojen oikeuksia ja vastuita. Neljänneksi, julkinen innovaatio muuttaa oikeuksia määritellä ja arvioida tuotannon arvoa. Viidenneksi, julkinen innovaatio vetoaa erilaiseen normatiiviseen viitekehykseen innovaatioiden arvioinnissa.

Kollaboratiivinen innovaatio edellyttää julkisella sektorilla kolmen kriteerin täyttymistä (Bommert 2010). Ensimmäinen kriteeri on, että yhteiskehittäminen avataan sisäisesti ja ulkoisesti merkityksellisille tekijöille. Toiseksi, julkishallinnon kulttuuristen rajoitteiden johdosta prosessin on mahdollistettava riskinotto. Kolmanneksi, kollaboratiivinen innovaatio promotoi sosio-poliittisessa ympäristössä ideaa positiivisesta suhtautumisesta koskien julkisen sektorin innovaatioita ja riskinottoa. Kollaboratiivisessa innovaatiossa ajatellaan, että ulkopuolisten toimijoiden osallistamisessa on monia hyviä puolia: samalla kun riskienotto laajenee, kansalaisia tuskin syyllistetään julkisten varojen väärinkäytöksistä samalla tavoin kuin virkamiehiä. Koska kollaboratiivinen innovaatio laajentaa sosio-poliittista ympäristöä vastaanottavaisemmaksi julkisia innovaatioita kohtaan, se vähentää julkishallinnon kulttuurisia rajoitteita.

Tutkimukset eri maissa ovat osoittaneet, että julkiset innovaatiot perustuvat lähinnä julkishallinnon sisäisiin prosesseihin sen sijaan, että huomiota kiinnitettäisiin uusiin palveluihin tai vai- kuttavuuden parantamiseen. Kehittämisideoita tulee lähinnä sisäisistä lähteistä, kuten julkisjohtajilta itseltään ja toisinaan heidän alaisiltaan. Paljon vähäisemmissä määrin julkiset innovaatiot tehdään yhteistyössä kansalaisten, talouden tai ulkoisten sidosryhmien kanssa. Näin ollen julkinen innovointi jää käytännössä muutaman yksilön harteille. Innovaatio tulisikin huomioida kokonaisvaltaisella tavalla: julkisorganisaation poliittis-rakenteellisessa kontekstissa, organisaation strategiassa, organisaation käytännöissä ja ihmisten sekä kulttuurin piirteissä. (Bason 2010: 14-16, 25.)

Kuten sanottua, julkishallinnon kulttuuriset rajoitteet muodostavat vakavan uhan tekoälyn kehittämiselle. Kirjallisuudessa tiedostetaan byrokraattisten rakenteiden organisationaaliset ja kulttuuriset rajoitteet, jotka heikentävät tutkimusprosessin toteutumista (Moore 2005, 2009; Hartley 2005; Harris \& Albury 2009; Mulgan \& Albury 2003). Nämä rajoitteet liittyvät esimerkiksi hierarkioihin, siiloutuneisiin rakenteisiin, ylhäältä alaspäin suuntautuviin prosesseihin jne. Riskin välttely rajoittaa johtajuutta, rahoitusta ja kokeilua sekä kasvattaa pelkoa epäonnistumisesta ja kansalaisten luottamuksen pettämisestä.

Eräs ilmentymä uudesta hengestä julkisella sektorilla on innovaatiokäsitteistön ja -johtamisen tuominen julkishallinnon ja -palvelujen kehittämiseen. Suomessa näkökulmaa on käytetty tähän asti terveydenhuollon kehittämisessä. Kyseinen teema on kuitenkin laajenemassa koskemaan julkista sektoria kokonaisuudessaan. (Lovio \& Kivisaari 2010: 7.) Toisaalta oma kysymyksensä on, miten käsitteistö toteutuu käytännössä - vaarana on sen jääminen puheen tasolle. Esimerkiksi Valtiovarainministeriön (2016) kysely virkamiehille osoitti, että innovatiivisuuden arvon koettiin vastaavan henkilön viraston toimintaa arvoista heikoiten. Tekoälyn ja julkisen sektorin rajapintaa voidaankin arvioida hallinnollisten tehtävien tasolla. Suomessa sovellusalueet ovat perustuneet luonnollisen kielen käsittelyyn, luokitteluihin ja ennusteisiin, kuten liikenneonnettomuusilmoitusten luokitteluun, kyberturvallisuuden apuvälineisiin ja lyhyen aikavälin talousennusteisiin. Hallinnollisten tehtävien laajentumista vaikeuttavat tällä hetkellä esimerkiksi lainsäädännön puutteet ja päällekkäisyydet. (Valtioneuvoston kanslia 2018, 18-20.) 


\section{KOHTI TEKOÄLYN YHTEISKEHITTÄMISTÄ}

Bason (2010) määrittelee kollaboratiivisen innovaation yhteiskehittämisen (co-creation) käsitteen kautta. Innovaatioekosysteemissä tapahtuva innovointi ei perustu yhteistyöhön vaan ajatteluun yhteiskehittämisestä. Tällainen suunnittelu perustuu seitsemään askeleeseen:

1. Rajaaminen. Jotta ongelman alue voidaan tunnistaa.

2. Tietämys. Nykytilanteen konkreettinen tuntemus, jolloin tutkitaan ihmisten jokapäiväistä elämää ja ongelmia esimerkiksi etnografisten menetelmien avulla. Käyttäjät ja sidosryhmät osallistetaan aktiivisesti suunnitteluun.

3. Analyysi. Nykyisten asiantilojen analyysi abstraktien kategorioiden kautta, joiden puitteissa nähdään järjestelmän yksittäiset ulottuvuudet ja osat.

4. Synteesi. Eri osien kokoaminen potentiaalisesti uusien ja kokonaisvaltaisten ratkaisujen luomiseksi.

5. Luominen. Luodaan eri ratkaisumallien prototyyppejä, joita voidaan testata käytännössä.

6. Skaalaus. Uusien ratkaisujen esitteleminen suurelle yleisölle.

7. Oppiminen. Yhteiskehittäminen on iteratiivinen prosessi, jonka aikana virheistä pyritään oppimaan. (Bason 2010, 140.)

Kauppinen ja kumppanit (2018) kritisoivat Basonin mallia siitä, ettei se noudata avoimen innovaation periaatetta: mallissa korostuvat esimerkiksi liiallinen julkishallintolähtöisyys ja kansalaisosallistumisen vähäisyys. Johtuen Basonin prosessin puutteista, Kauppinen ym. ovat luoneet oman prosessinsa, joka korostaa entisestään kollaboraation merkitystä. Sen askeleet perustuvat rajaamiseen, haasteeseen, yhteiskehittämiseen, valintaan ja tukeen sekä implementointiin. Ajatuksena on, että prosessin laajempi avaaminen kansalaisille kasvattaa ulkopuolisia ideoita. Näin ollen kansalaisten tulisi saada osallistua niin aiheen rajaamiseen, haasteen määrittelyyn kuin yhteiskehittämiseenkin. Vasta näiden askelten jälkeen valinta ja tuki (rahallinen tuki ja konsultointi innovaatioprosessin ulkopuolisten toimijoiden kanssa) sekä implementointi jää julkisen toimijan tehtäväksi.

Tällainen malli on lähellä Osbornen (2017) määritelmää julkisesta palveluhallitsevasta logiikasta (Public Service-Dominant Logic), jossa kansalaiset ja asiakkaat nähdään merkittäviksi sidosryhmiksi julkisessa politiikassa ja palveluntuotannossa. Ajatellaan, että julkisen palvelun palvelulupaus perustuu asiakkaiden odotuksiin. Yhteinen tuotanto (co-production) asiakkaiden kanssa tulisikin muodostaa tulevaisuuden julkisen palvelun ytimen. Viimekätisenä tavoitteena Osbornen teoriassa on tehokkuuden ja vaikuttavuuden parantaminen.

Basonin (2010), Kauppisen ja kumppaneiden (2018) sekä Osbornen (2017) mallien perusteella voidaan tehdä alustava suunnitelma tekoälyn yhteiskehittämiselle julkisella sektorilla. Tekoälyn innovaatioekosysteemiä voidaan luonnostella alla olevan kuvion mukaisesti:

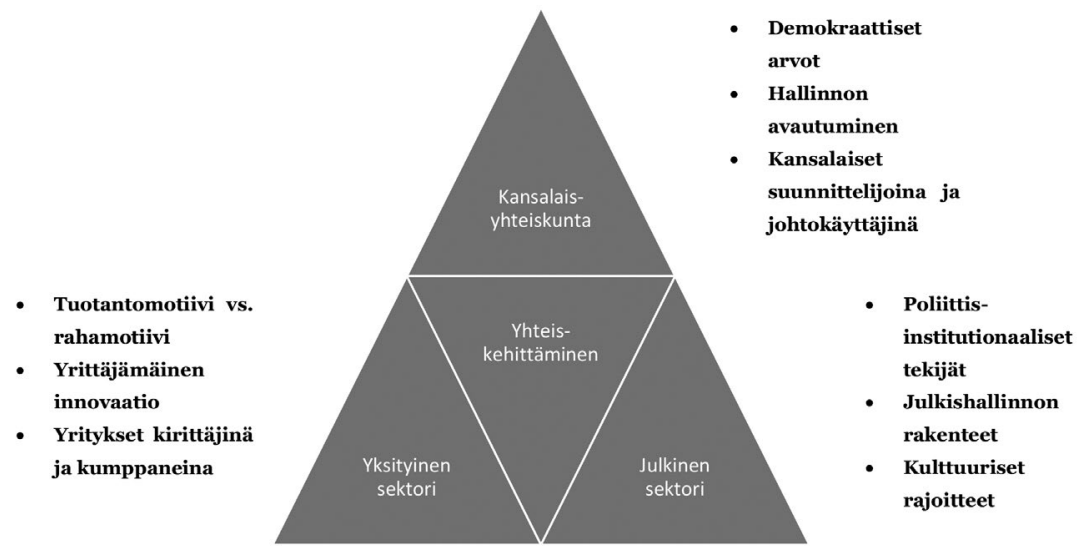

Kuvio 1. Tekoälyn julkinen innovaatioekosysteemi 
Kuvio 1 perustuu kansalaisten, yksityisen sektorin ja julkisen sektorin yhteiskehittämiseen. Julkisen sektorin roolia määrittelevät poliittisinstitutionaaliset tekijät, julkishallinnon rakenteet ja kulttuuriset rajoitteet. Näistä erityisesti kahta viimeistä on läpikäyty tässä artikkelissa. Puolustukseksi sanottakoon, että poliittis-institutionaaliset tekijät ovat läsnä niin julkishallinnon rakenteissa kuin kulttuurisissa rajoitteissakin. Lisäksi erityisesti poliittinen ulottuvuus on ajasta ja paikasta riippuvaista. Kansalaisyhteiskunnan rooli hahmottuu yhteiskehittämisen kautta demokraattisten arvojen, hallinnon avautumisen ja kansalaiskäsityksen uudelleen määrittymisen kautta: kansalaiset otetaan nyt mukaan julkisten palveluiden suunnitteluun. Yksityisen sektorin rooli perustuu tuotantomotiivin ja rahamotiivin dikotomiaan, yrittäjämäisten innovaatioiden luomiseen ja julkisen sektorin kirittämiseen ja kumppanuuksien hakemiseen. Kaiken kaikkiaan tekoälyn innovaatiojärjestelmä toteuttaa uuden julkishallinnan periaatteita hallinnon avautumisesta, verkostojen luomisesta ja poikkisektoraalisten toimijoiden välisestä yhteistyöstä.

Kuvion 1 prosessia voidaan avata tarkemmin yhteiskehittämisen kautta. Tekoälyn kollaboratiivisen innovaation vaiheet perustuvat innovaation rajaamiseen, haasteeseen, tietämykseen, yhteiskehittämiseen, skaalaukseen ja oppimiseen. Mallissa on pyritty huomioimaan ymmärrys tekoälyn ja hallinto-oppien rajoista ja mahdollisuuksista. Tätä ymmärrystä pyritään avaamaan kollaboraatioon osallistuville toimijoille rajaamisen, haasteen ja tietämyksen vaiheissa. Johtuen tekoälyn erityispiirteistä, kollaboraation on hyvä perustua työpajoihin, joissa aiheeseen perehdyttäminen ja ideoiden välittäminen on mahdollisimman ongelmatonta. Vaikka kollaboraatio perustuu yhteistyölle, julkisen toimijan on tärkeää pitää kiinni asemastaan prosessin hallinnoijana. Joka tapauksessa suunnittelun joka vaiheessa on olemassa riskejä, jotka vaikeuttavat prosessin onnistumista. Yhteiskehittämisessä huomioidaan OECD:n (2019) määrittelemät arvoperustaiset periaatteet tekoälyn suunnittelemiselle.

Rajaaminen. Tekoälyn yhteiskehittäminen perustuu inklusiivisen kasvun, kestävän kehityksen ja ihmiskeskeisten arvojen periaatteisiin (OECD 2019). Tekoälyä yhteiskehitetään kan- salaisille, yhteiskunnalle ja julkiselle sektorille. Tekoäly osana kansalaiset huomioivaa julkishallinnollista ohjelmaa. Kollaboraatio nähdään julkisena ja sosiaalisena innovaationa, jota ajaa ensisijaisesti tuotantomotiivi. Näin ollen innovointi on lähtökohtaisesti sosiaalista. Kollaboraatio edellyttää kyseisten kriteereiden yhteistä tunnustamista, mikä rajaa myös prosessissa olevien toimijoiden arvoja ja intressejä.

Riskit. Julkinen toimija ei tunnusta rajaamisessa kansalaisyhteiskunnan vaatimuksista, vaan pitää kiinni valta-asemastaan ongelmien määrittelijänä. Suunnitteluprosessissa vallitsee vaillinainen ymmärrys tekoälyn mahdollisuuksista, mikä vaikeuttaa ongelman rajaamista. Suunnittelun askelmerkeistä ja arvoista ei yhteisymmärrystä.

Haaste. Julkishallinnon haasteena on sidosryhmien valtuuttaminen luotettavan tekoälyn kehittämiseksi yhteiskunnallisiin tarpeisiin ja taloudellisen lisäarvon tuottamiseksi (OECD 2019). Julkishallinnon erikoispiirteet huomioon ottaen tekoälyä voidaan kehittää parhaiten byrokraattisten käytäntöjen piirissä.

Riskit. Tekoälyn esteinä toimivat kulttuuriset ja rakenteelliset rajoitteet julkisella sektorilla. Johtuen julkishallinnon kommunikoinnin hierarkkisuudesta ja muodollisuudesta, yhteiskehittäminen ei kohdistu vaadittaviin kehityskohteisiin. Suunnitteluprosessiin osallistuvilla toimijoilla vaikeuksia hahmottaa haastetta. Yritykset, järjestöt ja kansalaiset eivät huomioi julkishallinnon erityistekijöitä.

Tietämys. Vaiheessa keskeistä ovat läpinäkyvyyden ja selitettävyyden periaatteet: julkisten toimijoiden ei tulisi pelkästään vaalia yleistä tietämystä tekoälystä, vaan jakaa sidosryhmille tietoa niiden vuorovaikutuksesta tekoälyn kanssa (OECD 2019). Keskeistä on myös muiden kuin julkisten toimijoiden tietämyksen ymmärtäminen ja välittäminen. Ongelmaa rajaa ja haastaa julkinen toimija, mutta tietämyksen jakaminen, ratkaisumallien punninta ja päätöksenteko tapahtuvat yhteisesti. Julkisorganisaatiot toimivat eri tavoin kuin esimerkiksi yritykset: Plesner ja kumppanit (2017) väittävät, että julkisorganisaatioiden teknologisessa kehityksessä tulisi huomioida muodolliset byrokraattiset rakenteet, tilivelvollisuussuhteet ja virkamiesten professionaaliset kompetenssit. 
Riskit. Kansalaisten ja yritysten vaillinainen ymmärrys liittyen julkisorganisaatioiden rakenteista. Julkisorganisaatioiden vähäinen kommunikointi ja tietämyksen jakaminen. Tietämystä vaikea kääntää sovellettavaksi tiedoksi. Opportunistinen toiminta.

Yhteiskehittäminen. Tekoälyä ja sen sovellutusalueita luodaan yhdessä kollaboraatioon osallistuvien toimijoiden kesken. Tekoälyä tulee kehittää tavalla, joka kunnioittaa lakia, ihmisoikeuksia, demokraattisia arvoja ja arvojen monimuotoisuutta (OECD 2019). Yhteiskehittämisen vaihe on laajalti riippuvaista edellisten vaiheiden onnistumisesta. Myös toimijoiden tietämyksellä on keskeinen merkitys. Yhteiskehittäminen muuttaa julkisten palveluiden valtasuhteita.

Riskit. Kansalaisten näennäisvaikuttaminen aidon osallistamisen sijaan. Luottamuksen vähyys suunnitteluun osallistuvien osapuolten välillä. Yksityisen sektorin rahamotiivin ja yksityisen intressin vähäinen huomiointi julkisen toimijan toimesta.

Skaalaus. Tekoälysovellutuksia esitellään mahdollisesti prototyypin avulla julkisorganisaatiolle ja tämän jälkeen laajemmalle yleisölle. Ratkaisumalleja voidaan testata yhteiskehittämisen ulkopuolisessa organisaatiossa. Vaiheessa on tärkeää myös investointi tekoälyn tutkimukseen ja kehittämiseen (OECD 2019). Tärkeää on myös tekoälyn sovellutusalueen kontrollointi. Skaalauksen laajuutta määrittää yhteiskehittämisen onnistuminen.

Riskit. Yleinen skaalauksen vaikeus ja riippuvuus kontekstuaalisista tekijöistä. Siiloutuneet julkisorganisaatiot. Ulkopuolison organisaation rooli verkostossa.

Oppiminen. Onnistumisista ja virheistä oppiminen iteratiivisesti. Vastuu oppimisesta on viime kädessä julkisella toimijalla, sillä yhteiskehittämisen jälkeen toimijoiden välinen verkostomainen yhteistyö voi loppua täysin. Vaiheessa keskeistä on digitaalisen ekosysteemin ylläpitäminen, kansainvälinen yhteistyö muiden julkishallintojen kanssa ja poliittisen ympäristön muovaaminen tekoälylle otolliseksi alueeksi (OECD 2019).

Riskit. Yhteiskehittämisen pitäminen projektiluontoisena kokeiluna. Mitään konkreettista ei syntynyt. Yhteiskehittämisen ennenaikainen leimaaminen epäonnistuneeksi (ensimmäinen versio innovaatiosta on harvoin lopullinen).

\section{LOPUKSI}

Tässä artikkelissa on arvioitu tekoälytutkimusta, hallinto-oppien soveltuvuutta tekoälylle sekä tekoälyn yhteiskehittämistä innovaatioekosysteemissä. Artikkelissa on luonnehdittu tekoälyn mahdollisuuksia julkisella sektorilla ja julkisen innovaation merkitystä kyseisten mahdollisuuksien toteuttajana. Artikkelissa läpikäytiin Dreyfusin tekoälykritiikkiä, julkisen sektorin hallinnollisten kerrostumien (byrokraattinen hallinto, NPM, NPG) soveltuvuutta tekoälyyn ja viimeiseksi julkisen innovaation erityispiirteitä.

Tekoälyn sovellutusalueet koskettavat erityisesti byrokraattista hallintoa, jonka puitteissa innovoinnille ei löydy kulttuurisia tai rakenteellisia edellytyksiä. Pahimmassa tapauksessa byrokraattisen hallinnon kulttuuriset piirteet heikentävät yhteiskehittämistä ja tekoälyn soveltamista julkishallinnossa. Toisin sanoen hierarkkiset byrokratiat eivät ole optimaalisia julkisten innovaatioiden luomiselle. Samaan aikaan nämä samat byrokratiat ovat kuitenkin optimaalisia tekoälyn sovellutusalustoja. Tämä ristiriita korostaa julkisen innovaation ja yhteiskehittämisen tärkeyttä byrokraattisen käytäntöjen uudelleenmäärittelijänä. Kysymys ei kosketa pelkästään tekoälyn yhteiskehittämistä, vaan julkista innovaatiotoimintaa kokonaisuudessaan. Näin ollen tekoälyn kehittäminen julkisella sektorilla edellyttää yhteistyötä kansalaisten sekä eri sektoraalisten toimijoiden välillä kuitenkin niin, että päävastuun ottaa julkinen toimija.

Teknologiautopismia tulee vältellä, ja tekoälyn konkreettiset tulokset julkishallinnossa ovat toistaiseksi kyseenalaisia. Plesner ja kumppanit (2017) väittävätkin, että teknologiset reformit perustuvat usein digitalisaation imperatiiviin, jota kyseenalaistetaan harvoin. Ne, mitkä kollaboratiivisen innovaation käytännöt todellisuudessa toimivat ja mitkä eivät, jää toistaiseksi nähtäväksi. Näihin kysymyksiin vastaaminen edellyttää empiiristä tutkimusta. Yksi ilmeinen jatkotutkimusehdotus liittyy yhteiskehittämisen johtamiskompetensseihin julkisella sektorilla, ja se syventäisi entisestään verkostoissa johtamisen tutkimusaihetta hallintotieteessä. Toinen keskeinen kysymys liittyy tutkimus- ja kehitystoiminnan arviointiin tekoälyn yhteiskehittämisessä. Artikkelin puitteissa aihe on jäänyt käsittelemättä, vaikka se onkin tärkeä innovaatioekosysteemiä luonnehdittaessa. 


\section{LÄHDELUETTELO}

Andler, Daniel (2000). Context and background: Dreyfus and cognitive science. Teoksessa Wrathall, Mark \& Malpas, Jeff (Eds.), Heidegger, Coping and Cognitive Science (s. 137-160). London: MIT Press.

Angulo, Cecilio \& Godo, Lluis (2007). Artificial Intelligence Research and Development. Berlin: IOS Press.

Autioniemi, Jari (2017). Kohti hyvää hallintoa, kohti yleistä etua? Tiedepolitiikka 42:1 7-15.

Bason, Christian (2010). Leading Public Sector Innovation: Co-Creating for a Better Society. Bristol: The Policy Press.

Birkinshaw, Julian \& Gibson, Cristina (2004). Building ambidexterity into an organization. MIT Sloan Management Review, 45, 47-55.

de Vries, Hanna, Bekkers, Victor \& Tummers, Lars (2014). Innovation in the Public Sector: A Systematic Review and Future Research Agenda. Speyer: EGPA conference.

Bommert, Ben (2010). Collaborative innovation in the public sector. International Public Management Review, 11(1), 15-33.

Bengio, Yoshua \& LeCun Yann (2007). Scaling learning algorithms towards AI. Teoksessa Bottou Leon, Chapelle, Olivier, DeCoste Dennis \& Weston, Jason (Eds.), Large Scale Kernel Machines. New York: MIT Press.

Chesbrough, Henry W. (2003). Open Innovation: The New Imperative for Creating and Profiting from Technology. Harvard Business School Press.

Collins, Harry (2000). Four kinds of knowledge, two (or maybe three) kinds of embodiment, and the question of artificial intelligence. Teoksessa Wrathall, Mark \& Malpas, Jeff (Eds.), Heidegger, Coping and Cognitive Science. London: MIT Press, s. 179-198.

Dennett, Daniel (1995). Darwin's Dangerous Idea: Evolution and the Meaning of Life. New York: Simon \& Schuster.

Dreyfus, Hubert (1979). What Computers Can't Do: The Limits of Artificial Intelligence. London: MIT Press.

Dreyfus, Hubert (1992). What Computers Still Can't Do: A Critique of Artificial Reason. London: MIT Press.

Easton, David (1965). A Systems Analysis of Political Life. New York: John Wiley.

Efron, Sara Efrat \& Ruth, Ravid (2018). Writing the Literature Review: A Practical Guide. New York: The Guilford Press.
Eggers, William D., Schatsky, David \& Viechnicki, Peter (2017). AI-augmented Government: Using Cognitive Technologies to Redesign Public Sector Work. Deloitte University Press.

Harris, Michael \& Albury, David (2009). Why radical innovation is needed for the recession and beyond: The innovation imperative. NESTA Discussion Paper, March.

Hartley, Jean (2005). Innovation in governance and public services: Past and present. Public Money \& Management, 25(1), 27-34.

Heidegger, Martin (2002). Oleminen ja aika. Tampere: Vastapaino.

Hippel, Eric von (2005). Democratizing Innovation. London: The MIT Press.

Husserl, Edmund (2012). Eurooppalaisten tieteiden kriisi ja transsendentaalinen fenomenologia. Helsinki: Gaudeamus.

Hyyryläinen, Esa (2012). Johtaminen rationaalisuuteen pyrkivänä päätöksentekona. Teoksessa Hyyryläinen, Esa (toim.), Näkökulmia hallintotieteisiin (s. 46-62). Vaasa: Vaasan yliopisto.

Jackson, Deborah J. (2011). What is an Innovation Ecosystem? Haettu osoitteesta: http://erc-assoc. $\mathrm{org} /$ sites/default/files/topics/policy_studies/ DJackson_Innovation\%20Ecosystem_03-15-11. pdf (viitattu 24.9.2019)

Jansson, Gabriella \& Erlingsson, Gissur (2014). More e-government, less street-level bureaucracy? On legitimacy and the human side of public administration. Journal of Information Technology \& Politics, 11(3), 291-208.

Kauppinen, Sami, Luojus, Satu, Tähtinen, Lassi (2018). Towards Paradigm Shift in Public Sector Innovation. EURAM 18. Research in Action - Accelerating Knowledge Creation in Management, European Academy of Management.

Lovio, Raimo \& Kivisaari, Sirkku (2010). Julkisen sektorin innovaatiot ja innovaatiotoiminta: Katsaus kansainväliseen kirjallisuuteen. Espoo: VTT.

Lähdesmäki, Kirsi (2003). New Public Management ja julkisen sektorin uudistaminen. Tutkimus tehokkuusperiaatteista, julkisesta yrittäjyydestä ja tulosvastuusta sekä niiden määrittelemistä valtion keskushallinnon reformeista Suomessa 1980-luvun lopulta 2000-luvun alkuun. Acta Wasaensia. Vaasa: Vaasan yliopisto.

March, James G. (1991). Exploration and exploitation in organizational learning. Organization Science, 2(1), 71-87. 
Mehr, Hila (2017). Artificial Intelligence for Citizen Services and Government. Harvard Kennedy School, Ash Center for Democratic Governance and Innovation.

Menzel, Donald (2005). State of the art of empirical research of ethics and integrity in governance. Teoksessa Frederickson, H. George \& Ghere, Richard (Eds.), Ethics in Public Management (s. 16-48). New York: M.E. Sharpe.

Merleau-Ponty, Maurice (2012). Phenomenology of Perception. London: Routledge.

Moore, Mark (2005). Breaking-through innovations and continuous improvement: Two different models of innovative processes in the public sector. Public Money and Management, 25(1), 43-50.

Moore, Mark (2009). Networked government. Teoksessa Goldsmith, Stephen \& Kettle, David (Eds.), Unlocking the Power of Networks: Keys to High-Performance Government. Washington, DC: Brookings Institution Press.

Moore, Mark \& Hartley, Jean (2008). Innovations in governance. Public Management Review, 10(1), 3-20.

Mulgan, Geoff (2006). The process of social innovation. Innovations: Technology, Governance, Globalization, 1(2), 145-162.

Nambisan, Satish (2008). Transforming Government through Collaborative Innovation. IBM Center for the Business of Government.

Neyland, Daniel \& Möllers, Norma (2016). Algoritmic IF ... THEN rules and the conditions and consequences of power. Information, Communication \& Society, 20(1), 45-62.

Nyholm, Inga, Stenvall, Jari, Airaksinen, Jenni, Pekkola, Elias, Haveri, Arto, af Ursin, Klaus \& Tiihonen, Seppo (2016). Julkinen hallinto Suomessa. Helsinki: Art house, Tietosanomat.

OECD (2019). Recommendation of the Council on Artificial Intelligence. OECD/LEGAL/0449.

Oh, Deog-Seong, Phillips, Fred, Park, Sehee \& Lee, Eunghyun (2016). Innovation ecosystems: A critical examination. Technovation, 54(1), 1-6.

Osborne, Stephen P. (2010). Introduction. The (new) public governance: A suitable case for treatment? Teoksessa Osborne, Stephen P. (Ed.), The New Public Governance? (s. 1-16). London: Routledge.

Osborne, Stephen P. (2017). From public service-dominant logic to public service logic: Are public service organizations capable of co-production and value co-creation? Public Management Review, 20(2), 225-231.
Petrakaki, Dimitra \& Kornelakis, Andreas (2016). "We can only request what's in our protocol": Technology and work autonomy in healthcare. New Technology, Work \& Employment, 31(3), 223-237.

Plesner, Ursula, Justesen, Lise \& Glerup, Cecilie (2017). The transformation of work in digitized public sector organizations. Journal of Organizational Change Management, 31(5), 1176-1190.

Polit, Monique \& Talbert, Thierry (2006). Artificial Intelligence Research and Development. IOS Press.

Pollitt, Christopher (2010). Not Odious but Onerous: Comparative Public Administration. Public Administration, 89(1), 114-127.

Pollitt, Christopher \& Bouckaert, Geert (2011). Public Management Reform: A Comparative Analysis. Oxford: Oxford University.

Riccucci, Norma M. (2010). Public Administration: Traditions of Inquiry and Philosophies of Knowledge. Washington D.C.: Georgetown University Press.

Salminen, Ari (2011). Mikä kirjallisuuskatsaus? Johdatus kirjallisuuskatsauksen tyyppeihin ja hallintotieteellisiin sovelluksiin. Vaasan yliopiston julkaisuja. Opetusjulkaisuja, julkisjohtaminen 4.

Savoie, D.J. (2010). New Public Leadership for Public Service Reform. Teoksessa Pierre, Jon \& Ingraham, Patricia W. (Eds.): Comparative Administration Change and Reform: Lessons Learned (s. 259-277). London: McGill-Queen's University Press.

Searle, John (1980). Minds, brains, and programs. Behavioral and Brain Sciences, 3(3), 417-457.

Simon, Herbert A. (1946). The proverbs of administration. Public Administration Review, 6(1), 53-67.

Vainio, Arttu, Viinamäki, Olli-Pekka, Pitkänen, Sari \& Paavola, Juho-Matti (2017). Asiointi julkisessa hallinnossa: Kansainvälinen vertailu. Valtioneuvoston selvitys- ja tutkimustoiminta. Valtioneuvoston kanslia.

Valtioneuvoston kanslia (2019). Algoritmi päätöksentekijänä? Tekoälyn hyödyntämisen mahdollisuudet ja haasteet kansallisessa sääntely-ympäristössä. Valtioneuvoston selvitys- ja tutkimustoiminnan julkaisusarja 44/2019.

Valtioneuvoston kanslia (2018). Ohjelmistorobotiikka ja tekoäly: soveltamisen askelmerkkejä. Valtioneuvoston selvitys- ja tutkimustoiminnan julkaisusarja 65/2018. 
Valtioneuvoston kanslia (2017). Osaaminen ja työllisyys digimurroksessa. Valtioneuvoston selvitysja tutkimustoiminnan julkaisusarja 24/2017. Valtiovarainministeriö (2016). Virkamiesetiikan tila 2016: Kyselytutkimus valtion virkamiesten arvoista ja etiikasta. Valtiovarainministeriön julkaisu 38/2016. Helsinki: Valtiovarainministeriö. Vartola Juha (2009). Byrokratia modernin hallinnan muotona. Teoksessa Karppi Ilari, Sinervo Lotta-Maria (toim.), Governance: Uuden hal- lintatavan jäsentyminen (s. 13-43). Tampere: Tampereen yliopisto.

Veblein, Thorstein (2009). The Theory of the Leisure Class. Oxford: Oxford University Press.

Weber, Max (1972). Wirthshaft und Gesellschaft. Grundriss der Verstehenden Soziologie. Tübingen: Mohr.

Wittgenstein, Ludwig (1981). Filosofisia tutkimuksia. Helsinki: WSOY. 